\title{
Models for payment mechanisms for forest ecosystem services in Papua New Guinea, Philippines and Thailand
}

Jintana Kawasaki ${ }^{\text {* }}$, Henry Scheyvens ${ }^{a}$, Adcharaporn Pagdee ${ }^{b}$, and Canesio D. Predo ${ }^{c}$

a Institute for Global Environmental Strategies (IGES), Japan

$b$ Department of Environmental Science, Khon Kaen University, Thailand

c College of Forestry and Natural Resources, University of the Philippines Los Baños, Philippines

* Corresponding author. Email: jintana.kawasaki@mx.iges.or.jp

\section{ABSTRACT}

Forests of the Asia-Pacific region are being converted to other land uses or degraded because their ecosystem services have no market value. This project aimed to generate scientific knowledge on the design of effective payment systems for forest ecosystem services (PFES). The research was conducted at three sites where forests are facing increasing pressures: a community forest in Papua New Guinea, a sub-watershed forest in the Philippines, and a protected forest in Thailand. We identified ecosystem values, reviewed laws and institutions relevant to PFES implementation, assessed payment and pricing options, and proposed effective PFES models appropriate for each of the research sites. PFES schemes received positive responses from relevant sectors in all three sites. However, a lack of comprehensive understanding, especially on financing mechanisms and benefit distribution, may hinder PFES-project development. Capacity building of local governments and communities is needed to advance their action, that includes PFES mechanisms, effective forest management and sustainable agriculture.

\section{INTRODUCTION}

Forests in the Asia-Pacific region are being cleared for other land uses or degraded because their ecosystem services have no market value. To reduce deforestation and forest degradation, people need to be more aware of forest ecosystem services and their values. Forest valuation can also provide decision-makers with information for land-use planning and forest management. The estimated values of forest ecosystem services can be used for the development of Payments for Forest Ecosystem Services (PFES) schemes (Costanza et al., 2014), which can provide an alternative source of funding for forest conservation and restoration.

A PFES scheme is a system for generating finance to protect and/or restore forests, based on the provision of one or more ecosystem services. The concept of PFES is based on the principle that those who provide forest ecosystem services (sellers) should be remunerated for the continuous provision of such services. At the same

\section{KEYWORDS}

Forests, Payment for ecosystem services, Willingness-to-pay

\section{DOI}

https://doi.org/10.30852/sb.2020.1170

\section{DATES}

Received: 13 February 2020

Published (online): 5 November 2020

Published (PDF): 15 December 2020

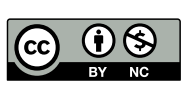

This work is licensed under a Creative Commons Attribution-NonCommercial 4.0 International License.

\section{HIGHLIGHTS}

» Comprehensive analyses of key forest ecosystem services and their economic values; policies, strategies and institutions relating to effective forest management and sustainable livelihoods; and transaction costs and payments options are crucial for effective guidelines for PFES-project development. Successful payment mechanisms must address economic efficiency (cost internalization), social vitality (equitable benefit distribution and sustainable livelihoods) and ecosystem balance (resilience and sustainable ecosystem services).

» PFES may offer an alternative approach for effective forest protection, but successful development of PFES-projects requires comprehensive understanding from all relevant sectors, especially on financing mechanisms and benefit distribution. It is the first step in a long road ahead. 
time, those benefiting (buyers), or others who are acting on behalf of the users (i.e. governments, non-governmental organizations (NGOs), etc.), should pay for the provision of the ecosystem services (Smith et al., 2013; Wunder, 2005).

There are high expectations that PFES could provide the necessary financial incentives for sustainable forest management; however, the PFES schemes have been slow to develop in the Asia-Pacific region. Factors hampering the development of PFES schemes include lack of stakeholder collaboration and lack of data on ecosystem service values to support PFES agreements.

The APN research project entitled "Effective models for payment mechanisms for forest ecosystem services in Papua New Guinea, Philippines and Thailand", aimed to generate knowledge on how PFES could contribute to forest conservation in areas where forests are facing increasing pressures. The research objectives were to (1) Identify a cost-effective and scientifically robust method to assess forest ecosystem services; (2) Determine key steps to establish the institutional frameworks and activities for ecosystem protection and service generation; (3) Compare pricing and payment mechanisms between voluntary and compulsory options based on scientific quantification and valuation of forest ecosystem services; and (4) Strengthen the capacity of stakeholders for identification, assessment and delivery of forest ecosystem services.

\section{METHODOLOGY}

The study's overall framework is shown in Figure 1.

\subsection{Study sites}

The project selected three different research sites to examine how PFES mechanisms could be developed in very different settings. The three case studies were: (1) Payment for carbon storage in a community-managed forest in Papua New Guinea (PNG); (2) Payment for maintaining and protecting forests in the upstream of a sub-watershed to reduce downstream flood damage in the Philippines; and (3) Payment for watershed forest protection in a protected national park to secure adequate water supply in drought-prone areas of northeastern Thailand.

The PNG research site was Ugalingu Forest, which lies within the Middle Ramu Block 1 Forest Management Area in Sogeram Valley, Usino Bundi District, Madang Province. The research site is located in the Central Hills, which consists of closely dissected steep-sided hills and short ridges that rise to $240 \mathrm{~m}$ above sea level. The research site holds over 1,400 ha of pristine lowland hill tropical rainforest. By protecting this forest from logging, the high carbon stocks that the forest holds would also be protected. The Philippines site (Silang-Santa Rosa Subwatershed and Cambantoc Subwatershed in the province of Laguna) is vulnerable to natural hazards, such as typhoons and floods, accelerated by climate change. The forests contribute to flood mitigation. The sub-watershed flows from the mountainous area of Silang, Cavite, passes through Silang-Sta. Rosa river, and eventually drains into the Laguna lake. Upland areas of the sub-watershed are composed of built-up areas, agricultural and mixed croplands, grasslands and mixed

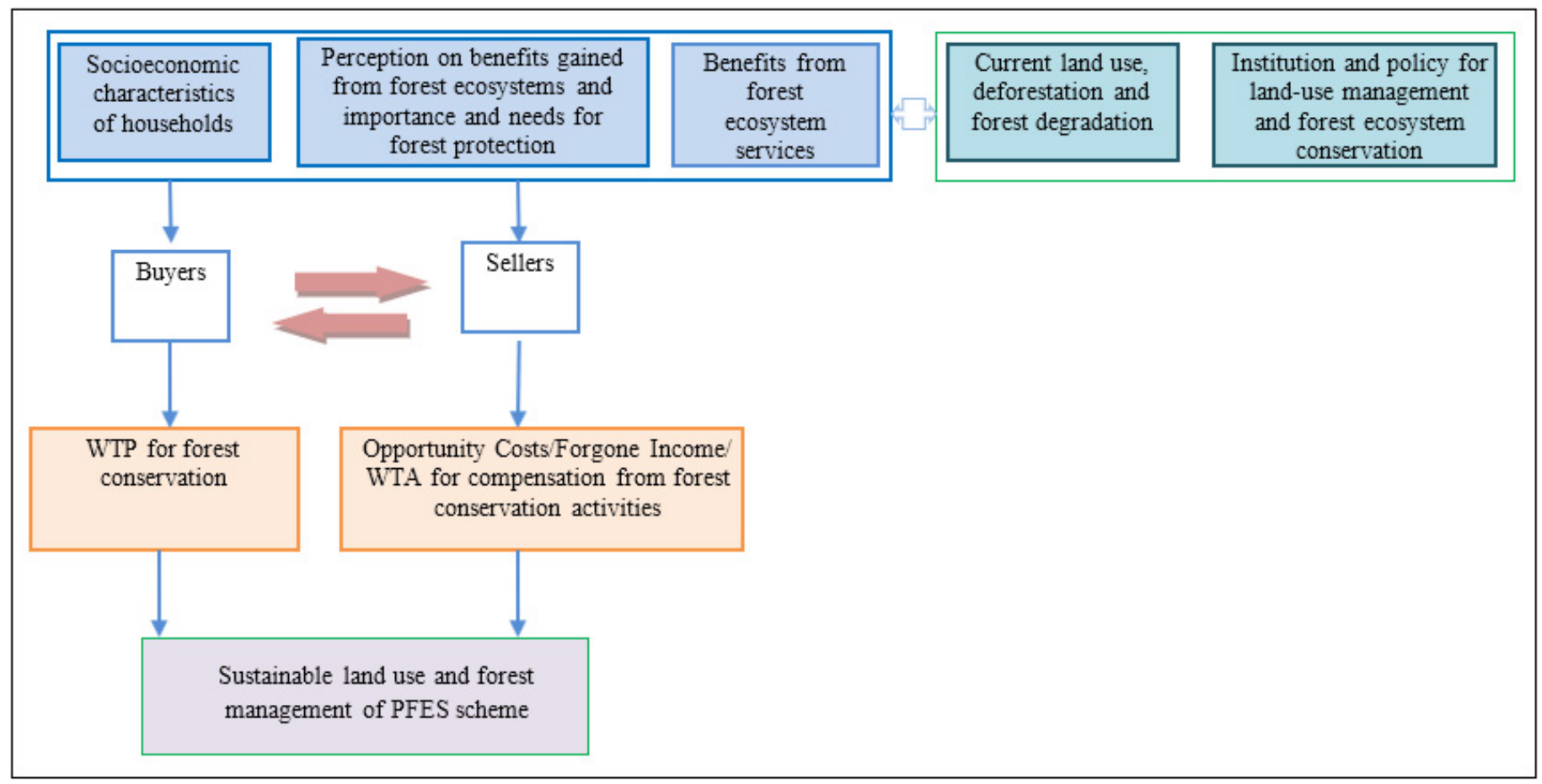

FIGURE 1. The overall framework of the study. 
scrub, broadleaf or forest vegetation, while lowland areas are mostly used as built-up areas, grassland or idle land, and agricultural and rice fields. The Thailand site (Phu Kao in Phu Kao-Phu Phan Kham National Park in Nong Bua Lamphu province) provides water, drought mitigation and non-timber forest products (NTFPs) that support local livelihoods. The park is located between latitudes $16^{\circ} 46^{\prime}-17^{\circ} 022^{\prime} \mathrm{N}$ and longitudes $102^{\circ} 24^{\prime}$ $102^{\circ} 43^{\prime} \mathrm{E}$, covering approximately 32,200 ha $\left(322 \mathrm{~km}^{2}\right)$. Primary vegetation includes dry Dipterocarp forest (approx. $70 \%$ of the park), followed by mixed deciduous forest and dry evergreen forest (approx. $20 \%$ of the park area).

\subsection{Methods}

The methodology consisted of three sets of activities:

(1) Socioeconomic surveys and forest ecosystem services analysis, through forest measurements, field investigations, questionnaires and key informant interviews. At the PNG site, Verified Carbon Standard (VCS) methodologies were used to estimate the avoidance of emissions by protecting community-owned and managed forests from industrial-scale logging. In Thailand and the Philippines, buyers' willingness to pay (WTP) and sellers' willingness to accept (WTA) of PFES deals for forest protection were estimated, together with analyses of factors influencing villager decision-making using logistic regressions. The study used household questionnaires for cost-benefit analyses of ecosystem services by asking the respondent's WTP for ecosystem protection and sustainable service provision (following Khuc, Alhassan, Loomis, Tran, \& Paschke, 2016; Boyle, 2003). A Contingent Valuation Method was used to estimate the monetary values of non-marketed ecosystem services (following Bateman et al, 2002; Carson, 2000).

(2) Analysis of policies, laws, strategies and institutions relating to forest protection and ecosystem service provisions. It was done through literature review and key informant interviews. Laws, policies and other institutions at national, regional and municipal levels were assessed on whether they help facilitate PFES-project development in each of the studied countries.

(3) Assessment of transaction costs and payment options (following Wunder, Engel, \& Pagiola, 2008; Fripp, 2014). Several methods were used at each of the research sites to analyze transaction costs and payment options. These included the analysis of the profitability of farming systems based on questionnaire interviews of villagers and the analysis of opportunity costs for participating in PFES schemes (i.e. adopting tree-based plantations (Thailand), agroforestry farming systems
(Philippines), and protection of forest carbon stocks [PNG]). The arrangements for setting up the PFES schemes at the research sites were drawn from discussion with villagers, government authorities and lessons learned from the research.

\section{RESULTS AND DISCUSSION}

At the Thailand study site, local livelihoods depend on agriculture, especially cash cropping of rice, cassava and sugarcane. The watershed forest provides water and NTFPs as food and income sources for the local communities. The average total amount of harvested NTFPs were $79 \mathrm{~kg} /$ household/year of which bamboo shoots, frogs and mushrooms were the three most common products. Two groups of direct beneficiaries of these forest ecosystem services were identified: (1) the three villages' members inside Phu Kao; and (2) villagers living outside the park. The estimated gross economic value of the NTFPs was 295 USD/year, or approximately $10 \%$ of the annual household income during 2018-2019. However, forest degradation from agricultural encroachment and harvesting of NTFPs at the Thailand site affected the watershed forest structure and ecosystem services, leading to inadequate water supply for agriculture and household uses. In the case of people living outside the park, continuing water shortage will affect farming and loss in their farm incomes with at least $32 \%$ of the annual household income. Nearly all of the villagers (98\%) expressed the need for forest protection and restoration, emphasizing the importance of reforestation and effective water management in the watershed areas of the park.

The study received positive responses on the idea of PFES from local communities both those who live inside the park (sellers) and villagers living outside the park (buyers), with $56 \%$ of WTP and $55 \%$ of WTA, respectively. Key variables used in WTP and WTA models included (1) dummy variables for WTP of households living outside the park and WTA of households inside the park; (2) offered bid amounts for forest conservation; and (3) socioeconomic variables influencing household decisions (age, education, income, etc.). The estimated WTP was 4 USD/month/household, while WTA was 7 USD/month/household. The imbalance between demand and supply indicated an unattainable market unless financial subsidies are considered. Respondents who disagreed with the payment scheme expressed that PFES-project would reduce their benefits from the watershed forest, especially food sources and income generated from NTFPs.

The study also set up hypothetical conditions as part of a PFES project where agroforestry or a tree-based 
system was employed as a key mechanism to reduce forestland encroachment, especially due to agricultural expansion in the three villages inside Phu Kao. Switching from cash-crops to tree-based plantations introduces opportunity costs due to a decrease in cash-crop planting areas. Villagers provided data on monetary costs and benefits under major land-use types (rice, cassava, sugarcane, mixed perennials and forest), which were used to estimate opportunity costs of land-use change employing Net Present Value (NPV). NPV was calculated to estimate the profitability of land use over 10 years. An annual discount rate of $5 \%$ was applied for years with profit and $0 \%$ for years without profit. The calculated NPVs were: mixed tree and perennial crop cultivation, 4,342 USD/ha; forestlands, 178 USD/ha; rice, 6,934 USD/ ha; cassava, 9,830 USD/ha.

Findings suggest that agroforestry and reforestation promotion as part of the PFES scheme will result in income loss for villagers who participate in forest conservation activities in Phu Kao. To reduce the impact as a result of income loss, while providing incentives to participate in PFES project development, villagers must be provided with sufficient compensation and/or alternative income sources such as from carbon offsets. Moreover, Thailand does not have specific legal support for PFES-project development, including implementation guidelines, rules and regulations and responsible authorities. This makes it difficult for PFES projects to develop and grow. The Office of Natural Resources and Environmental Policy and Planning should consider developing policies and plans, especially implementation guidelines with clear legal support, to facilitate PFES-project development in the country. Technical supports are also needed, and this can be provided by universities and research institutes working closely with local government and communities.

At the Philippines site, forest products were the most frequently chosen as key ecosystem services by respondents $(36.82 \%)$, followed by water purification $(20.90 \%)$, air purification $(18.91 \%)$ and flooding mitigation $(15.92 \%)$, respectively. Downstream households are the main beneficiaries of ecosystem services, particularly flood mitigation. The majority of households incurred income loss (about 63 USD per household) during severe flood events. Leading causes of deforestation and forest degradation in upstream areas were logging (84.58\%) and forest conversion to agricultural lands (15.92\%). The responses strongly expressed that human activities were the main responsibility for flooding. The majority of respondents in downstream areas agreed with the implementation of forests protection and rehabilitation activities, especially agroforestry in upstream areas. However, since farmers' adoption of sustainable forest/ land measures in upstream areas will incur some income losses, downstream households should compensate upstream farmers through a PFES scheme. In upstream areas, most farmers' current land use is mixed perennials $(40 \%)$, while $32 \%$ practice rice monoculture. The net return of rice monoculture (997 USD/ha) was lower than mixed agriculture (2,737 USD/ha).

The probability for downstream households to pay and upstream households to accept compensation for forest conservation is assumed to depend on their socioeconomic characteristics (age, years of education, income, etc.). The expected amounts of WTA per month (5 USD/household) from upstream households were higher than the expected amounts of WTP (7 USD/household) of downstream households. There is thus a need for negotiation on the ecosystem service's price. The study found that land conversion from forests to agricultural lands was a prominent reason for soil erosion in many cases. If tree-based systems are integrated into farming systems with other sustainable management measures to mitigate flooding and soil erosion at the research site, it will result in income loss for farmers. Conversion of rice monoculture to perennial monoculture $(8,900$ USD/ ha) has the highest opportunity costs in the Cambantoc Subwatershed, while in the Silang-Santa Rosa Subwatershed, it is conversion of pineapple monoculture to mixed perennials $(22,710$ USD/year).

Adoption of nature-based approaches such as timber-based farming systems can contribute to flood mitigation. However, there is a need for a better understanding of tree species selection. Suitability of tree species to certain areas, profitability and ability to reduce surface run-off were found to be among the factors that can motivate farmers to adopt tree-based farming systems. Also, the research found that to avoid conflict, existing laws that govern natural resources must be compatible with PFES. Furthermore, coordination between organizations of the sellers and buyers is also crucial for effective and efficient management of PFES.

At the PNG site, the project researched the potential for PFES at Ugalingu forest. Ugalingu forest covers 1,400 ha and is owned under customary tenure by the Ugalingu clan, who reside in Koromosarik Village. The livelihoods of Ugalingu are largely subsistence-based, though small amounts of cash flow into the community through wage labour and sale of agricultural produce. The main agricultural cash crop is cocoa, with most households having a cocoa plot. Agriculture provides food on the table, and the forest provides supplementary food, materials for buildings and tools, medicines and cultural practices.

Ugalingu forest is a tract of pristine tropical rainforest that lies within an active logging concession. The study estimated net greenhouse gas emissions that 
could be avoided by protecting Ugalingu forest from the logging operation. Two land-use scenarios for Ugalingu forest over the next 30 or so years can be foreseen. The first is that the forest remains intact and undisturbed, as at present. The second and most likely scenario is commercial logging in the project area by an outside logging company using heavy machinery and in weak compliance with the logging code of practice, followed by the penetration of shifting agriculture in some parts of the project area. Verified Carbon Standard (VCS) approved methodologies VMo010 and VMo011 were used for the assessment. The research used existing inventory data and new primary data generated from a biomass survey using 12 of $35 \times 35 \mathrm{~m}$ plots to estimate forest carbon stocks in aboveground living biomass for trees with a diameter at breast height ( $\mathrm{dbh}$ ) greater than $5 \mathrm{~cm}$. The assessment estimated total avoided emissions over the first 10 years of a PFES project to protect carbon stocks in Ugalingu forest of 80,670 tCO2e.

In terms of national policies and institutions, there is no direct support for a community-based PFES scheme in PNG. Also, there is no single government agency responsible for overseeing a PFES exchange. Furthermore, if a PFES market were to be developed under current legislation, it would be completely unregulated (Crane, 2015). Protection of carbon stocks in Ugalingu forest from logging would be understood under the national policy as a REDD+ activity. PNG's National REDD+ Strategy allows project proposals from landholders, private sector actors and NGOs. However, they must be able to demonstrate clear competencies within the areas of project development and a strong commitment to the ongoing support and development of communities within the project location, as well as a secure long-term financial investment.

In estimating transaction costs for a PFES scheme to support the protection of forest carbon stocks by the customary landowners from logging of their forest, it was assumed that an NGO would manage the PFES project in PNG that has expertise in forestry and community development. The rough estimate of setting up PFES for Ugalingu forest protection was USD241,000.

\section{CONCLUSION}

Research at the three sites showed that development of PFES schemes requires a large amount of diverse information. This includes information on (1) ecosystem values, (2) policies and laws, (3) buyers' preferences and

\begin{tabular}{|c|c|c|c|}
\hline & Thailand & Philippines & Papua New Guinea \\
\hline Location & $\begin{array}{l}\text { Phu Kao-Phu Phan Kham National } \\
\text { Park in Nong Bua Lamphu Province } \\
-26 \% \text { of the Phu Kao - Phu Phan } \\
\text { Kham National Park area is part of } \\
\text { the Ubolratana reservoir }\end{array}$ & $\begin{array}{l}\text { Sta. Rosa-Silang and Bay- } \\
\text { Cambantoc Subwatersheds, Laguna } \\
\text { Lake region }\end{array}$ & $\begin{array}{l}\text { Ugalingu forest ( } 1,400 \text { ha of pristine } \\
\text { lowhill rainforest), Middle Ramu } \\
\text { Block } 1 \text { Forest Management Area, } \\
\text { Sogeram Valley, Usino Bundi } \\
\text { District, Madang Province }\end{array}$ \\
\hline Issue & $\begin{array}{l}\text { Agricultural encroachment and } \\
\text { harvesting of NTFPs has affected } \\
\text { watershed forest structure, leading } \\
\text { to inadequate water supply for } \\
\text { agriculture and household uses. }\end{array}$ & $\begin{array}{l}\text { Deforestation and land-use change, } \\
\text { which is exacerbating downstream } \\
\text { flood risk }\end{array}$ & $\begin{array}{l}\text { Threat of industrial-scale logging to } \\
\text { existing forest carbon stocks }\end{array}$ \\
\hline Seller & $\begin{array}{l}\text { Three villages located inside the } \\
\text { park }(1,600 \mathrm{ha})\end{array}$ & Upstream households & Customary owners of Ugalingu forest \\
\hline Buyer & Villagers living outside the park & Downstream households & $\begin{array}{l}\text { Government or other party wishing } \\
\text { to purchase carbon offsets }\end{array}$ \\
\hline Services & $\begin{array}{l}\text { Water provision, drought } \\
\text { mitigation and NTFPs }\end{array}$ & Flood damage mitigation & Carbon storage in forest biomass \\
\hline $\begin{array}{l}\text { Analysis of } \\
\text { payment } \\
\text { scheme }\end{array}$ & $\begin{array}{l}\text { - Monthly WTP per household ( } 4 \\
\text { USD) and WTA ( } 7 \text { USD) } \\
\text { - Conversion of cassava ( } 9,830 \\
\text { USD/ha) and rice (6,934 USD/ } \\
\text { ha) monoculture to tree- } \\
\text { based plantation incurred high } \\
\text { opportunity cost. } \\
\text { - Promoting tree-based plantation } \\
\text { with sufficient compensation/ } \\
\text { carbon offsets is recommended. }\end{array}$ & $\begin{array}{l}\text { - Monthly WTP per household } \\
\text { (5USD) and WTA ( } 7 \text { USD) } \\
\text { - Conversion of rice monoculture } \\
\text { to perennial monoculture } \\
\text { ( } 8,900 \text { USD/ha) has the highest } \\
\text { opportunity cost in the Cambantoc } \\
\text { Subwatershed } \\
\text { - Local government units support } \\
\text { reforestation activities and promote } \\
\text { tree-based farming using their } \\
\text { generated funds }\end{array}$ & $\begin{array}{l}\text {-The estimated total avoided } \\
\text { emissions over the first } 10 \text { years is } \\
80,670 \text { tCO2e. } \\
\text {-Transaction costs for a PFES } \\
\text { scheme to support the protection } \\
\text { of forest carbon stocks by the } \\
\text { customary landowners from } \\
\text { the logging of their forest were } \\
\text { approximately } 241,000 \text { USD/project }\end{array}$ \\
\hline $\begin{array}{l}\text { Local policies } \\
\text { support for } \\
\text { PFES }\end{array}$ & None available & None available & $\begin{array}{l}\text { Can be supported under PNG's } \\
\text { National REDD+ Strategy }\end{array}$ \\
\hline
\end{tabular}

TABLE 1. PFES scheme in different ecosystem services types differentiated in Thailand, Philippines and Papua New Guinea forests. 
willingness-to-pay, (4) local community awareness, attitudes and perceptions on forest ecosystem services and their willingness to participate in a PFES scheme, (5) capacity of potential managers of the PFES scheme (communities, local governments, NGOs, etc.), and (6) activities that should be prioritized for forest management using the generated PFES funds. A first step before launching any PFES scheme is building the understanding of all stakeholders on the benefits of forest ecosystem services and the mechanics of PFES.

PFES can potentially provide an alternative source of financing for forest conservation and sustainable management of forests. All of the research sites were found to have the potential for PFES schemes, but there were also significant barriers. Analysis of WTP in Thailand and the Philippines showed that there is potential to generate funds locally from buyers of forest ecosystem services, but that the estimated WTA of sellers is higher than the estimated WTP of local buyers. In the case of PNG, the market price for carbon represents the WTP. Preliminary analysis suggests that this could be sufficient to cover a low-cost PFES scheme. For the research sites in Thailand and the Philippines, the results of WTP and WTA analysis can be presented to buyers, sellers and the local government as a starting point for negotiation on payment levels. The finding revealed that it is important for the local government and communities to have a good understanding of the mechanics of the PFES scheme and the benefits of adopting tree-based farming systems.

\section{ACKNOWLEDGEMENT}

We are grateful to the Asia-Pacific Network for Global Change Research (APN) for the financial support and guidance, to our colleagues for their collaboration, and to local communities, governmental authorities, NGOs and research institutes that supported and/or engaged with the research at the study sites in Thailand, Philippines and PNG.

\section{REFERENCES}

Bateman, I. J., Carson, R. T., Day, B., Hanemann, M., Hanley, N., Hett, T., ... \& Sugden, R. (2002). Economic valuation with stated preference techniques: a manual.

Boyle, K. (2003). Contingent valuation in practice. The Netherlands: Kluwer Academic Publishers.

Carson, R. T. (2000). Contingent valuation: A user's guide. Retrieved October 19, 2018, from Department of Economics University of California San Diego: http:// econweb.ucsd.edu/ rcarson/papers/CVusersguide. pdf

Crane, M. D. (2015). Payment for ecosystem services options and opportunities for New Britain Island Papua New Guinea. Port Moresby.

Costanza, R., Groot, R.D., Sutton, P., Ploeg, S.V., Anderson, S.J., Kubiszewski, I., . . Turner, R.K. (2014). Changes in the Global Value of Ecosystem Services. Global Environmental Change, 26(2014), 152-158.

Fripp, E. (2014). Payments for Ecosystem Services (PES) A practical guide to assessing the feasibility of PES projects. Retrieved June 06, 2019, from Center for International Forestry Research (CIFOR): https:// www.cifor.org/library/5260/

Khuc, Q. V., Alhassan, M., Loomis, J. B., Tran, T. D., \& Paschke, M. W. (2016). Estimating urban households' willingness-to-pay for upland forest restoration in Vietnam. Open Journal of Forestry, o6(03), 191-198. doi:10.4236/ojf.2016.63016

Smith, S., Rowcroft, P., Everard, M., Couldrick, L., Reed, M., Rogers, H., . . . White, C. (2013). Payments for ecosystem services: A best practice guide. Defra, London

Wunder, S. (2005). Payments for environmental services: Some nuts and bolts. Jakarta, Indonesia: Center for International Forestry Research.

Wunder, S., Engel, S., \& Pagiola, S. (2008). Taking stock: A comparative analysis of payments for environmental service programs in developed and developing countries. Ecological Economics 65(4): 834-52. 